\title{
LOW LIGHT PHYTOPLANKTON GENERA OBSERVED IN THE COASTAL AND ESTUARINE WATERS OF GOA, INDIA
}

\author{
RAMAKRISHNAN, R.* - ThAYAPURATH, S. - MANGUESH, U. G. - DiAS, A. B. \\ National Institute of Oceanography, Goa 403004, India \\ (e-mail: suresh@nio.org; phone: +91-83-2245-0365) \\ *Corresponding author \\ e-mail: reshmitharamakrishnan@gmail.com \\ (Received 20 $0^{\text {th }}$ Jul 2017; accepted $6^{\text {th }}$ Dec 2017)
}

\begin{abstract}
This is the first study carried-out to understand the phytoplankton genera in the low light (less than $50 \mu \mathrm{mol} / \mathrm{m}^{2} / \mathrm{s}$ of photosynthetically available radiation) for the estuarine and coastal waters of Goa, India. There were 93 phytoplankton genera observed of which the most abundant were Skeletonema spp., Leptocylindrus spp., Thalassiosira spp., Cerataulina sp., and Fragilariopsis sp. The centric diatom Skeletonema spp. was the most abundant phytoplankton genera observed during all the seasons. Similarly, other abundant genera observed all through the year in low light in the coastal and estuarine waters were Cerataulina sp., Chaetoceros spp., Coscinodiscus spp., Leptocylindrus spp., Navicula spp., Nitzschia spp., Pleurosigma spp., Pseudo-nitzschia spp., and Thalassiosira spp. Phytoplankton observed only in estuarine waters were Bacillaria sp., Planktoniella sp., Biddulphia sp., and Asterionellopsis spp., while Enotia sp., Oxytoxum sp., were observed only in the coastal waters during the summer season. Contributions of chlorophyll a and fucoxanthin were relatively higher in low light regions, while the photoprotective pigment $\beta$-carotene was lower than observed at the surface. The maximum spectral light available at the low light region varied for water types, and was 537 to $581 \mathrm{~nm}$ in the coastal waters, while it shifted to longer wavelengths 561 to 648 in the estuarine waters.
\end{abstract}

Keywords: coastal waters, estuaries, low light, photoacclimation, umbrophillic phytoplankton

\section{Introduction}

Light is the source of life on planet Earth. However, unlike the terrestrial environment where there is no dearth of solar light required for photosynthesis, the aquatic regions are not blessed to have sufficient light at all depths. Phytoplankton are planktons or 'wanderers' and have to survive wherever they are taken and hence phytoplankton have the abilities to survive at extreme light levels. The acclimation of phytoplankton under extreme light conditions are labeled related to light adaptations such as high light or sun or 'heliophillic' and adapted to low light or shade or 'umbrophillic' (Ryther and Menzel, 1959). Photoacclimation is their way of life (Dubinsky et al., 2010). Though it has been shown in laboratory studies that the minimum light level required by phytoplankton is about $2 \mu \mathrm{mol} / \mathrm{m}^{2} / \mathrm{s}$ (Overmann and Garcia-Pichel, 2005), the actually observed light levels are reported to be even lower (Raven and Cockell, 2006). They are very efficient at utilizing the energy and it has been observed that at the very low light respiration rates are much lower. Most of the microscopic $\mathrm{O}_{2}$ evolving organism of cyanobacteria and eukaryotes can have photolithotrophic growth, i.e. using photons as the sole energy to compensate irradiance as low as about $0.35 \mu \mathrm{mol} / \mathrm{m}^{2} / \mathrm{s}$ (Raven et al., 2000).

The light is spectral in nature with varying levels of energy inversely proportional to the wavelengths. Hence these phytoplankton in low light regions need to be studied for their photoacclimation and 'chromatic acclimation'. Though it has been argued that the spectral light was inconsequential and was believed earlier that photosynthesis required 
light in the PAR region (Dring, 1981), which however proved wrong with recent studies. Recent studies revealed that spectral light does play an important role in photosynthesis (Gorai et al., 2014).

The light harvesting capabilities can be appreciated when it is observed that there are extensive deep chlorophyll maxima observed just near the $1 \%$ of light levels (Moore et al., 2006; Dubinsky, 2010). The global primary productivity estimations do consider light levels only till $1 \%$ and it has been evident from various studies and observations that there were plenty of phytoplankton even below this light levels whose contributions were significant and cannot be ignored. There also seems to hold some relations with regards to their light utilization for photosynthesis between the taxonomic groups of phytoplankton and cell sizes observed in low light (Richardson et al., 1983; Geider et al., 1986; Cullen and Macintyre, 1998; Finkel, 2001; Boyd et al., 2010).

One of the earliest studies on phytoplankton community in the coastal and estuarine waters of Goa were from Devassy and Goes (1988) which provided information on the seasonal variations of phytoplankton communities in the coastal and estuarine waters. These drowned river valley type estuaries are known as 'monsoonal estuaries' and the monsoon has an influence on the phytoplankton community (Patil and Anil, 2011). Detailed studies of the phytoplankton in these estuaries exhibited the large diversities of the phytoplankton communities, with blooms and harmful algae (Matondkar et al., 2007; Patil and Anil, 2011; Pednekar et al., 2012, 2014).

Presently there is no information available of the phytoplankton composition in the low light regions of the waters of Goa. The availability of light at the benthic regions of the estuarine and coastal waters of Goa show spatial and temporal variations and there were regions in the water column that were under very low light. This is the first study that reports the phytoplankton genera at low light in these coastal and estuarine waters of Goa and the variations of physical, biological and optical parameters at these low light regions.

\section{Materials and methods}

\section{Study area}

The field measurements were carried out in the coastal and estuarine waters of Goa, a site located between latitude $15.3^{\circ}$ to $15.73^{\circ} \mathrm{N}$ and longitude 73.6 to $74.1^{\circ} \mathrm{E}$ at the central west coast of India (Fig. 1). The study areas included coastal waters and the two estuaries Mandovi and Zuari. One of the main factors that influence these waters are the rains during the southwest monsoon in the months of June to September hence they are often called as "monsoonal estuaries". Tides are the sole driving force for circulation and mixing in the estuaries during the non-monsoon season (Shetye et al., 2007; Vijith et al., 2009). There are much fewer discharges during the non-monsoon seasons and the waters are vertically well mixed. Monsoonal upwelling is the common feature observed during the south-west monsoon in the coastal waters of Goa, which plays an important role in the biogeochemistry of these waters. Seasonal hypoxia has been observed in the sub-surface waters during the post-monsoon period of September to October (Naqvi et al., 2000, 2006). The coastal waters have algal blooms of varied species, some of which are seasonal such as Trichodesmium blooms which were often observed during the summer season (Naqvi et al., 1998; Desa et al., 2005; Parab et al., 2006; Gomes et al., 2008). Temperature inversions were also reported in these waters (Thadathil and Gosh, 1992). Large variations in the colored dissolved organic matter 
$(\mathrm{CDOM})$ were observed in these waters with contrasting features in the estuarine and coastal waters (Dias et al., 2017).

The depth of the stations in the coastal waters varied between 2.5 to $26 \mathrm{~m}$ and 2 to 8 $\mathrm{m}$ in the estuaries. The optical studies indicate that Secchi depth varies from 2.1 to 3.1 $\mathrm{m}$ in the coastal waters and 1.2 to $2.4 \mathrm{~m}$ in the estuaries.

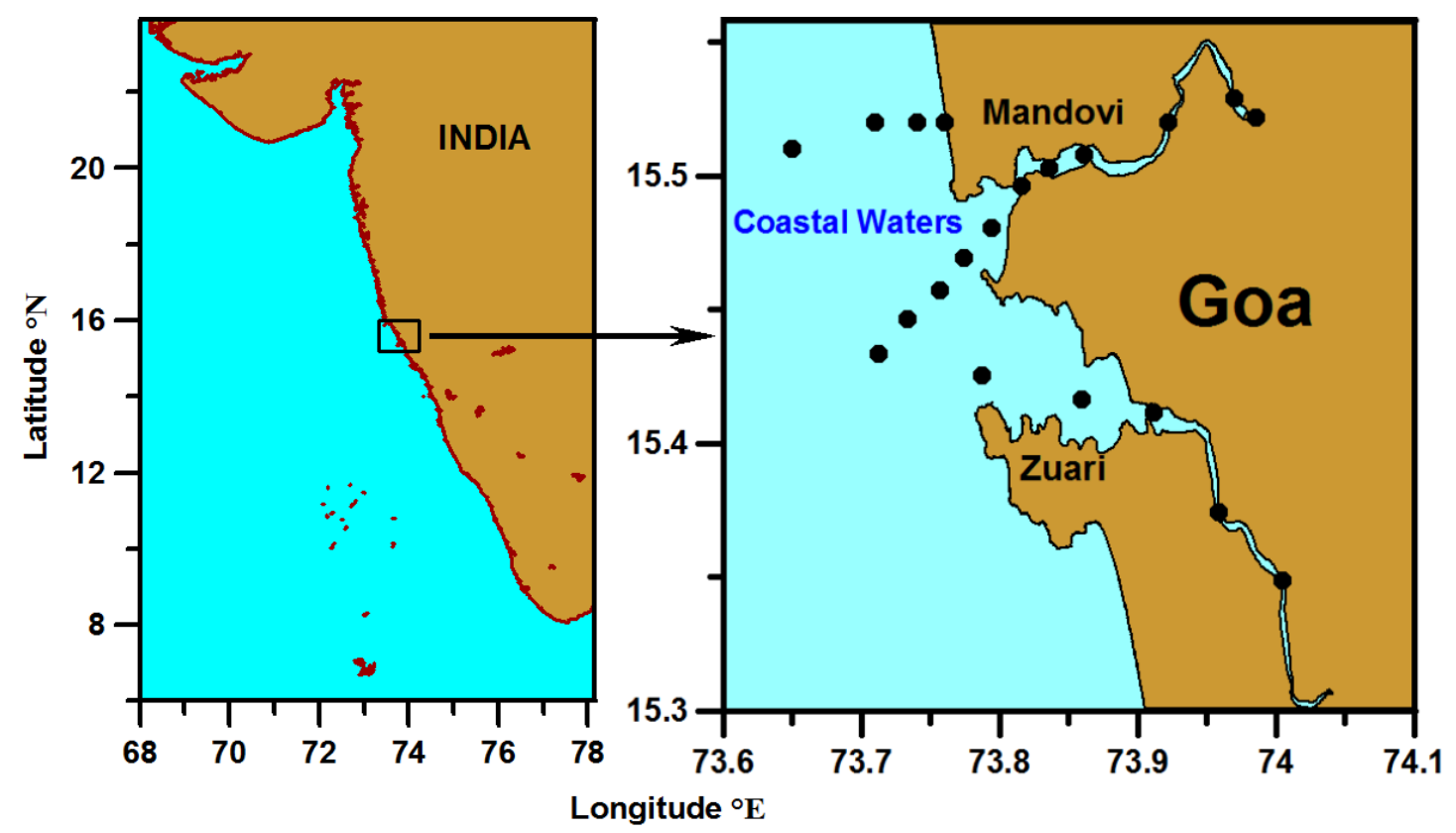

Figure 1. Study area showing water sample collections sites in the coastal and estuarine waters of Goa, India

\section{Environmental data and sample collection}

There were two types of data used for the study, the one that was available from the measurements using in-situ profiling instrument and the other available from the water samples collected at the same stations as in-situ measurements. The measurements and water samples were collected during field measurement campaigns on a boat in the coastal and estuarine waters every month during fair weather conditions at preidentified stations (Fig. 1). No measurements were carried out in the coastal waters during the monsoon period. The data include from the period 2013 to 2016 covering 50 stations of which 37 were in the estuaries and 13 in the coastal waters.

Most of the earlier studies related to low light and photoacclimation were restricted in the lower region of PAR about $30 \mu \mathrm{mol} / \mathrm{m}^{2} / \mathrm{s}$ (Fisher et al., 1996; Anning et al., 2000; Zastrow, 2001; Staehr et al., 2002; Rodriguez et al., 2006; Finkel et al., 2006; Dubinsky and Stambler, 2009) the data used for this study included only data at depths with PAR values less than $50 \mu \mathrm{mol} / \mathrm{m}^{2} / \mathrm{s}$, which is equivalent to about $12.5 \mathrm{~W} / \mathrm{m}^{2}$ of solar irradiance in PAR region (Suresh et al., 1996). Though the minimum value of PAR measured was about $0.22 \mu \mathrm{mol} / \mathrm{m}^{2} / \mathrm{s}$ this could be within small error considering the detection limit of the radiometer. The mean of the spectral dark readings taken in the laboratory was about $0.2 \mu \mathrm{W} / \mathrm{cm}^{2} / \mathrm{nm}$ and dark current readings were taken care during processing. All optical, physical, biological and ancillary parameters were obtained at the same depths of low light observations (Fig. 2). 

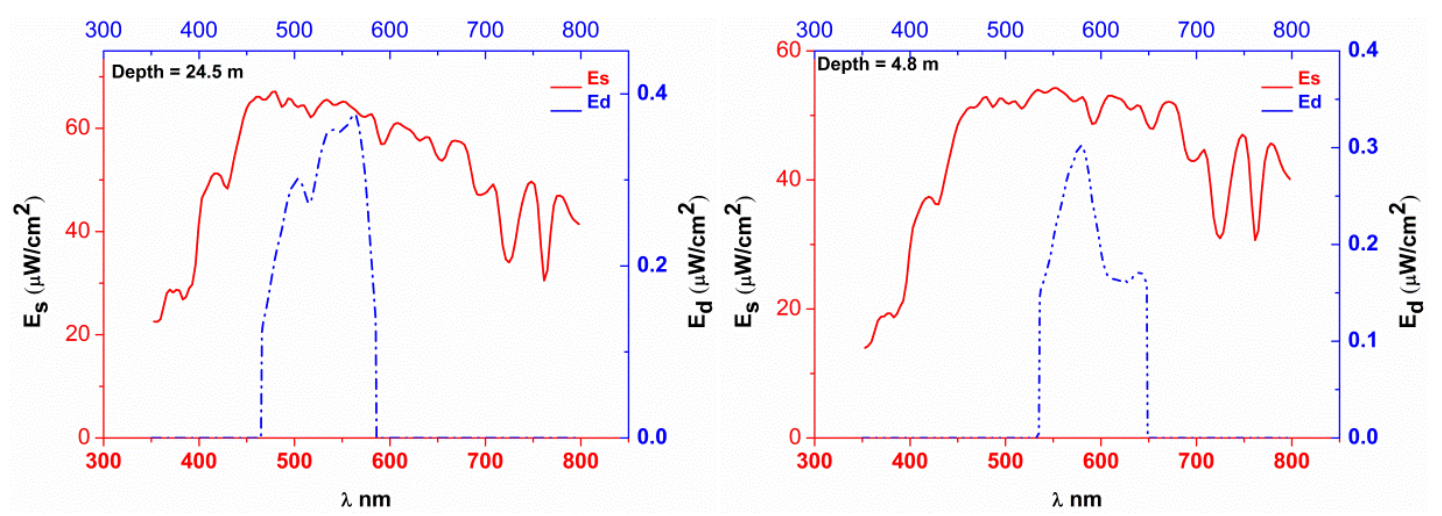

Figure 2. Solar irradiance at the surface of the water (straight line) and at low light region (dashed line) for the two stations in the coastal waters of Goa (left) and Mandovi estuary (right). Depth at low light is indicated in the top left corner of each diagram

The water samples were collected either by Niskin water sampler or automated water sampler using silicon transparent pipe with the pump. The water samples were used for analysis in the laboratory for phytoplankton taxonomy with light microscope (Olympus BX 51) and scanning electron microscope (Hitachi TM3030), and the same water sample were used for deriving chlorophyll using fluorometric method (Trilogy-Turner), total suspended matter using the gravimetric method, CDOM using spectrophotometer (Shimadzu UV-2600) and pigments using HPLC (Agilent 1100 series).

The water samples $(250 \mathrm{ml})$ were collected in amber colored plastic bottles and preserved following the method described by Santhanam et al. (1987) using $2 \mathrm{ml}$ of Lugol's iodine solution. For microscopic analysis, samples were concentrated to 5-10 $\mathrm{ml}$ by siphoning the top layer with a tube covered with a $10 \mu \mathrm{m}$ nytex filter on one end. Sample concentrates were transferred to a $1 \mathrm{ml}$ capacity Sedgwick-Rafter and counted using a light microscope (Olympus BX 50) at 20x and 40x magnification. Phytoplankton cell identifications were based on standard taxonomic keys (Tomas, 1997). The results were expressed as numbers of cells $\mathrm{L}^{-1}$.

The water samples collected at discrete depths were preserved and analyzed in the laboratory following the standard protocols. The biological parameter included colored dissolved organic matter (CDOM), chlorophyll (Chl), total suspended matter (TSM). The phytoplankton pigments were measured using HPLC. Apart from the biological parameters derived from the water sample analysis, the depth profiles of parameters such as CDOM, chlorophyll fluorescence were available from the optical sensors available with the hyper-spectral radiometer.

The optical properties were measured in-situ using profiling optical instruments. The apparent optical properties were derived from the measurements using a hyper-spectral profiling radiometer Hyper-OCR (Satlantic, Canada), which provided profiles of downwelling irradiance, upwelling radiance, diffuse attenuation coefficients, PAR (photosynthetically available radiation $(400-700 \mathrm{~nm})$ ) and surface solar irradiance in the spectral range of 350-800 $\mathrm{nm}$. The mean of the spectral dark readings taken in the laboratory was about $0.2 \mu \mathrm{W} / \mathrm{cm}^{2} / \mathrm{nm}$. This was considered as the detection limit. The surface irradiance data were available from a reference sensor mounted at a clear site on the boat. The inherent optical properties were measured using an AC-9 instrument (Wet Labs) which provided profiles of absorption and beam attenuation coefficient (without the contributions from pure water) at nine wavelengths. The instrument AC-9 was 
calibrated in the laboratory prior to every field measurement using optically clean water, whereas hyperspectral radiometer was periodically factory calibrated. The optical data were processed following the standard protocols (Mueller 2003, Mueller et al., 2003). The radiometer data were processed using the latest software Prosoft provided by the manufacturer of the radiometer.

The ancillary parameters such as temperature, salinity, and density were available from the profiling radiometer. Secchi depth was also measured.

\section{Results}

There were 93 phytoplanktons genera observed in the low light regions of coastal and estuarine waters of the study area and listed here are the 20 phytoplanktons genera and their abundance (Table 1). The abundance of phytoplankton genera is given as the percent of the total counts of all genera. Most of these genera listed here have also been reported earlier to reside in low light conditions such as Asterionella sp. (Zastrow, 2001), Chaetoceros spp. (Finkel et al., 2006), Coscinodiscus spp. (Key et al., 2010), Cyclotella sp. (Fisher et al., 1996), Ditylum sp. (Staehr et al., 2002), Fragilaria sp. (Karst-Riddoch et al., 2009), Prorocentrum sp. (Rodriguez et al., 2006), Skeletonema spp. (Anning et al., 2000), Synechococcus spp. (Barlow and Alberte, 1987), and Thalassiosira sp. (Dubinsky and Stambler, 2009). Most of the genera observed here were diatoms and diatoms can adapt to all light levels (Richardson et al., 1983).

Table 1. The physical environmental parameter for low light phytoplankton genera observed in coastal and estuarine waters of Goa

\begin{tabular}{c|c|c|c|c|c|c|c}
\hline $\begin{array}{c}\text { Low light } \\
\text { phytoplankton } \\
\text { genera }\end{array}$ & $\begin{array}{c}\text { Mean } \\
\text { percentage } \\
\text { occurrence }\end{array}$ & $\begin{array}{c}\text { Minimum } \\
\text { temp }\left({ }^{\circ} \mathbf{C}\right)\end{array}$ & $\begin{array}{c}\text { Maximum } \\
\text { temp }\left({ }^{\circ} \mathbf{C}\right)\end{array}$ & $\begin{array}{c}\text { Minimum } \\
\text { salinity }\end{array}$ & $\begin{array}{c}\text { Maximum } \\
\text { salinity }\end{array}$ & $\begin{array}{c}\text { Minimum } \\
\mathbf{d e n s i t y} \\
\left(\mathbf{k g} / \mathbf{m}^{\mathbf{3}}\right)\end{array}$ & $\begin{array}{c}\text { Maximum } \\
\mathbf{d e n s i t y} \\
\left(\mathbf{k g} / \mathbf{m}^{\mathbf{3}}\right)\end{array}$ \\
\hline Skeletonema spp. & 13.03 & 25.038 & 32.39 & 0.14 & 35.42 & 4.66 & 22.61 \\
Leptocylindrus spp. & 7.65 & 25.038 & 32.09 & 0.14 & 35.42 & 4.66 & 22.76 \\
Thalassiosira spp. & 7.46 & 25.038 & 31.18 & 2.81 & 35.31 & 4.66 & 22.61 \\
Cerataulina sp. & 6.93 & 27.485 & 32.33 & 2.81 & 35.74 & 4.66 & 22.58 \\
Fragilariopsis sp. & 6.70 & 32.346 & 32.35 & 31.88 & 31.88 & 18.61 & 18.61 \\
Chaetoceros spp. & 5.56 & 25.038 & 32.33 & 0.39 & 35.74 & 4.66 & 22.61 \\
Asterionellopsis spp. & 5.38 & 25.038 & 29.33 & 11.05 & 35.31 & 4.66 & 22.61 \\
Licmophora sp. & 4.76 & 25.038 & 31.19 & 11.96 & 35.42 & 4.79 & 22.61 \\
Navicula spp. & 4.70 & 25.038 & 32.35 & 0.14 & 35.74 & 4.66 & 22.76 \\
Oxytoxum sp. & 4.70 & 32.284 & 32.28 & 26.67 & 26.67 & 14.75 & 14.75 \\
Coscinodiscs spp. & 4.19 & 25.038 & 32.33 & 11.05 & 35.74 & 4.66 & 22.61 \\
Pseudo-nitzschia spp. & 4.07 & 27.111 & 32.28 & 0.14 & 35.42 & 4.66 & 22.43 \\
Nitzschia spp. & 3.76 & 25.038 & 32.35 & 0.14 & 35.74 & 4.66 & 22.76 \\
Heterocaps sp. & 3.50 & 32.284 & 32.28 & 26.67 & 26.67 & 14.75 & 14.75 \\
Prorocentrum spp. & 3.22 & 27.275 & 32.33 & 0.39 & 35.74 & 10.69 & 22.58 \\
Cochlodinium sp. & 3.20 & 27.275 & 32.33 & 11.05 & 35.09 & 4.66 & 22.52 \\
Pleurosigma spp. & 3.08 & 25.038 & 32.35 & 0.14 & 35.31 & 4.66 & 22.61 \\
Bacillaria sp. & 2.95 & 26.641 & 30.33 & 0.14 & 34.89 & 19.28 & 21.54 \\
Cyclotellas pp. & 2.89 & 25.038 & 32.35 & 11.05 & 35.74 & 4.66 & 22.61 \\
Dactyliosolen sp. & 2.53 & 25.038 & 32.09 & 0.39 & 34.81 & 4.66 & 22.61 \\
\hline
\end{tabular}


There were about 80 genera observed in the "very" low light regions (less than $5 \mu \mathrm{mol} / \mathrm{m}^{2} / \mathrm{s}$ of PAR). The leading twenty phytoplankton in these very low light regions as per their abundance were Skeletonema spp., Leptocylindrus spp., Thalassionema spp., Chaetoceros spp., Cerataulina sp., Bacillaria sp., Navicula spp., Nitzschia spp., Pseudo-nitzschia spp., Proboscia sp., Coscinodiscus spp., Prorocentrum spp., Dactyliosolen sp., Cylindrotheca sp., Lauderia sp., Pleurosigma spp., Licmophora sp., Thalassiosira spp., Eucampia sp. and Cyclotella spp. The images of ten most occuring low light phytoplankton are shown in Figure 3.

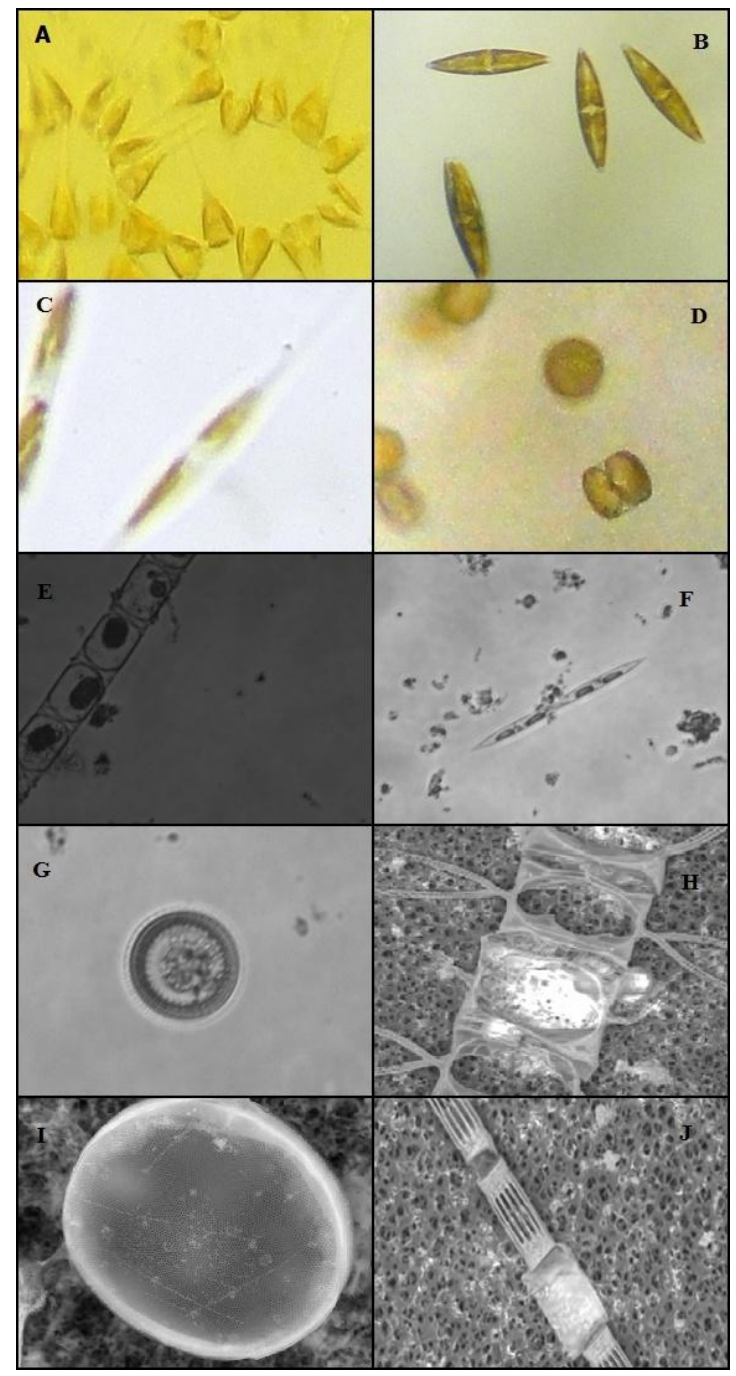

Figure 3. Microscopic images of A) Asterionellopsis sp., B) Navicula sp., C) Nitzschia sp., D) Thalassiosira sp., E) Cerataulina sp., F) Pseudo-nitzschia sp., G) Cyclotella sp., and SEM (Scanning electron microscope) images of H) Chaetoceros sp., I) Coscinodiscus sp., and J)

Skeletonema sp.

\section{Physical parameters}

The measurements on physical characteristics of the waters were taken during all seasons in estuarine and coastal (except monsoon) waters which showed large variations in salinity, temperature, and density over the period of study which were consistent with 
the earlier observations by others for these waters. The range of physical environmental parameters observed at the occurrences of these twenty genera in low light are given in Table 1. The temperature varied between 25.0 and $32.9{ }^{\circ} \mathrm{C}$, the salinity from 0.14 to 35.7 and density from 4.6 to $22.7\left(\mathrm{~kg} / \mathrm{m}^{3}\right)$.

\section{Morphology}

The shapes of phytoplankton genera observed in low light were mostly cylindrical, rectangular box, a prism on parallelogram base and spherical.

\section{Spatial and temporal variations}

To study the temporal pattern the seasons were labeled as summer (March-May), monsoon (June-September), post-monsoon (October-November) and winter (DecemberFebruary) season. The phytoplankton genera were selective in their adaptations to the seasons and water types. There were distinct patterns of adaption of phytoplankton genera observed with those noticed only on coastal waters or estuaries and during a particular season and while others inhabiting in all waters at all times.

Skeletonema spp., is a type of cylindrical, non-flagellated centric diatom group with cosmopolitan distribution and was the most frequently and abundantly observed genera in these waters during all season (Matondkar et al., 2007; Patil and Anil, 2011; Pednekar et al., 2014). Similarly, other genera observed all through the year in the coastal and estuarine waters were Cerataulina spp., Chaetoceros spp., Coscinodiscus spp., Leptocylindrus spp., Navicula spp., Nitzschia spp., Pleurosigma spp., Pseudonitzschia spp., and Thalassiosira spp.

Bacillaria sp., Planktoniella sp., Biddulphia sp., Isthmia sp., and Asterionellopsis spp., were only observed in estuarine waters (Matondkar et al., 2007). Enotia sp. and Oxytoxum sp., were observed only in the coastal waters during the summer season.

\section{Optical parameters}

There were two types of optical parameters, one that provided information on the amount of light available and the second that described the optical properties of water.

The optical parameters observed at these low light regions that quantified the amount of light available were photosynthetically available radiation (PAR) 400-700 nm, the percentage of PAR (\%PAR) and downwelling spectral solar irradiance (Ed) which were observed at depth and the spectral solar irradiance measured above the surface of the water.

There were also optical properties of water that described the light in these water. These included apparent and inherent optical properties. The inherent optical properties were absorption, beam attenuation, and backscattering coefficients. These parameters characterized the light conditions and suggested the reasons for the low light conditions. The apparent optical properties included the downwelling irradiance (Ed), PAR and diffuse attenuation coefficient $(\mathrm{Kd})$. The optical parameters that were indicators of the penetration of light were the transparency of water (Secchi depth) and first optical depth Z90.

The statistics of the observed optical parameters are listed in Table 2, and these parameters were observed at the water column depths where the PAR values were less than $50 \mu \mathrm{mol} / \mathrm{m}^{2} / \mathrm{s}$, which is equivalent to about $12.5 \mathrm{~W} / \mathrm{m}^{2}$ (Suresh et al., 1996). The $\%$ PAR were less than 10 in these waters. 
Table 2. Optical parameter observed during low light environmental condition at coastal and estuarine waters off Goa

\begin{tabular}{l|c|c|c|c}
\hline \multicolumn{1}{c|}{ Parameters } & Minimum & Maximum & Mean & SD \\
\hline PAR $\left(\mu \mathrm{mol} / \mathrm{m}^{2} / \mathrm{s}\right)$ & 0.21 & 50.86 & 13.45 & 15.79 \\
\%PAR & 0.01 & 8.21 & 1.33 & 1.70 \\
Wavelength of maximum solar irradiance at low light depth $(\mathrm{nm})$ & 534 & 648 & 577 & 21.90 \\
Maximum spectral irradiance of light at low light depth $\left(\mu \mathrm{W} / \mathrm{cm}^{2}\right)$ & 0.14 & 9.26 & 2.90 & 2.88 \\
Wavelength of maximum surface solar irradiance $(\mathrm{nm})$ & 460 & 551 & 494 & 30 \\
Maximum of surface spectral irradiance $\left(\mu \mathrm{W} / \mathrm{cm}^{2}\right)$ & 23.18 & 178.97 & 102 & 38.3 \\
Absorption at $412 \mathrm{~nm}\left(\mathrm{~m}^{-1}\right)$ (without water) & 0.29 & 12.74 & 2.33 & 2.46 \\
Absorption at $676 \mathrm{~nm}\left(\mathrm{~m}^{-1}\right)($ without water) & 0.03 & 0.65 & 0.16 & 0.11 \\
Beam attenuation at $412 \mathrm{~nm}\left(\mathrm{~m}^{-1}\right)($ without water) & 2.40 & 126.17 & 13.29 & 19.7 \\
Beam attenuation at $676 \mathrm{~nm}\left(\mathrm{~m}^{-1}\right)($ without water) & 1.66 & 141.61 & 10.44 & 20.6 \\
Back scattering coefficient at $676 \mathrm{~nm}$ & 0.02 & 0.90 & 0.16 & 0.18 \\
Diffuse attenuation coefficient at $490 \mathrm{~nm}$ & 0.009 & 4.26 & 1.1 & 0.88 \\
Wavelength at maximum $\mathrm{Z}_{90}(\mathrm{~nm})$ & 481 & 582 & 561 & 24 \\
Maximum $\mathrm{Z}_{90}(\mathrm{~m})$ & 0.55 & 8.15 & 2.38 & 2.0 \\
\hline
\end{tabular}

\section{Biological parameters}

The pigment data from HPLC analysis were available only for few stations in the low light region are reported here. From these limited data of phytoplankton pigments, apart from chlorophyll, the most abundant pigments were fucoxanthin, zeaxanthin, and $\beta$-carotene (Fig. 4). The contribution of the individual pigment to the total pigment was derived by normalizing the pigment values with the total pigments. Contributions of chlorophyll a and fucoxanthin were relatively higher in low light regions, while $\beta$ carotene was lower than observed at the surface. One of the noteworthy observations was the contribution of chlorophyll a to be above $60 \%$ at the low light region, while at the surface it was about $50 \%$.

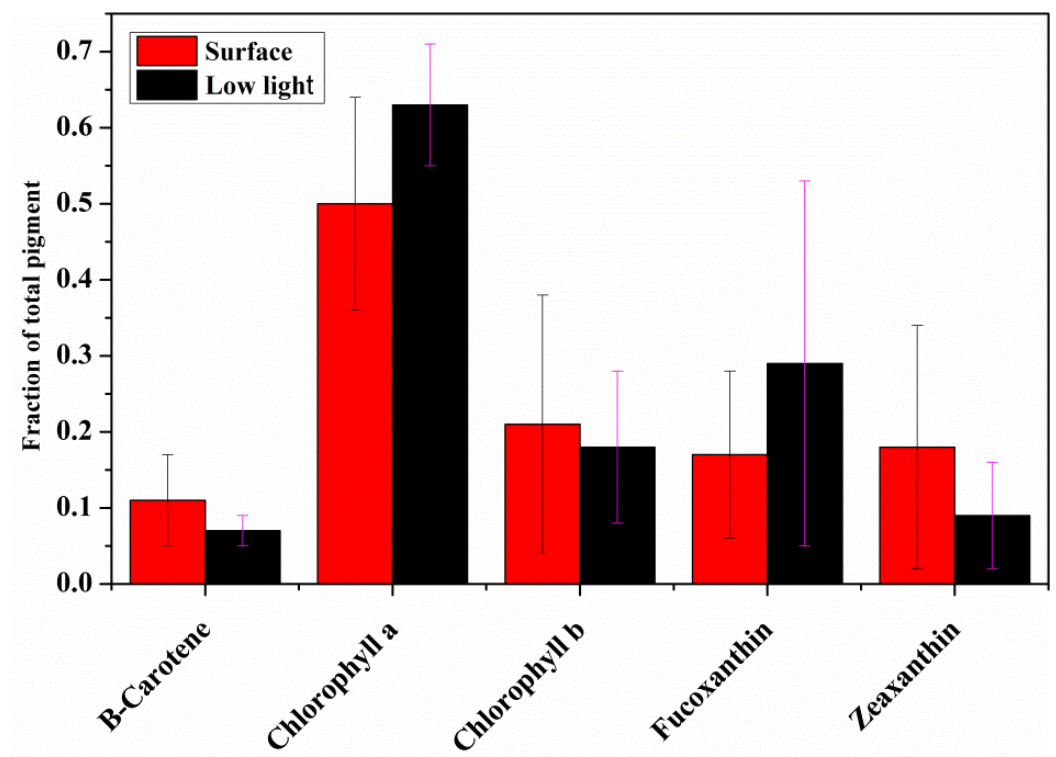

Figure 4. Phytoplankton pigments at the surface and low light region 
Apart from the information on the phytoplankton pigments, the other parameters available from waters samples analysis were chlorophyll, CDOM, and total suspended matter and supporting biological parameters measured with optical sensors available on profiling radiometer were CDOM and chlorophyll fluorescence. $\mathrm{pH}$ was determined with a hand held $\mathrm{pH}$ meter (Table 3). The values of chlorophyll, CDOM, and TSM were appreciable to the mean value of these parameters observed in the water column.

The presence of optically active substances that attenuate light and create low light conditions were evident from the high values of the optical properties such as absorption due to CDOM, absorption in the blue region at $412 \mathrm{~nm}$, beam attenuation coefficients (attenuation and scattering), high backscattering coefficient and diffuse attenuation coefficient. The biological parameters like CDOM and TSM were also found to be higher at the bottom. CDOM absorb light particularly in the blue and green region, leaving less light in the PAR region, while particles scatter and attenuate light. The high TSM could be due to the river transport and resuspension from the bottom.

Table 3. Biological parameters observed during low light environmental condition at coastal and estuarine waters of Goa

\begin{tabular}{l|c|c|c|c}
\hline \multicolumn{1}{c|}{ Parameter } & Minimum & Maximum & Mean & SD \\
\hline Chlorophyll $a\left(\mathrm{mg} / \mathrm{m}^{3}\right)$ & 0.4 & 12.83 & 3.9 & 2.9 \\
Total suspended matter $(\mathrm{TSM})\left(\mathrm{g} / \mathrm{m}^{3}\right)$ & 3.06 & 110 & 20.74 & 21.45 \\
CDOM absorption at $412 \mathrm{~nm}, \mathrm{a}_{\mathrm{g}}(412)\left(\mathrm{m}^{-1}\right)$ & 0.08 & 0.86 & 0.34 & 0.22 \\
CDOM fluorescence & 0.02 & 15.91 & 2.38 & 2.43 \\
Fluorescence & 0.3 & 3.74 & 1.32 & 0.83 \\
$\mathrm{pH}$ & 7.12 & 8.18 & 7.63 & 0.31 \\
\hline
\end{tabular}

\section{Discussion}

The low light regions are close to the bottom and the phytoplankton will require an adequate supply of nutrients for their sustenance. There is no dearth of nutrients in these estuaries (Verlencar, 1987). Mandovi and Zuari estuaries are also sources of nutrients to the coastal waters, though their concentrations are comparatively lower than estuaries. These help in the sustenance of the efficient light harvesting umbrophillic phytoplankton and seem to be the reason for the relatively higher chlorophyll found in these low light waters.

Photoacclimation by phytoplankton to extreme levels of light affects pigment ratios of these phytoplankton. Our observations on the distributions of pigments at high and low light show that chlorophyll and fucoxanthin were higher at low light levels, which agree with earlier studies that show light-harvesting pigments increase under low light and particularly chlorophylls, phycobilins, fucoxanthin and peridinin under low light (Dubinsky and Stambler, 2009; Pinchasov-Grinblat et al., 2011). $\beta$-carotene help in photoprotective mechanism under high light conditions and in low light conditions they are inconsequential so $\beta$-carotene were relatively lower (Krinsky, 1989; Fan et al., 1995; Choudhury and Behera, 2001; Wang et al., 2003; Schagerl and Muller, 2006). Fucoxanthin is associated with diatoms and used to indicate its abundance and its level was higher at low light regions than the surface. Most of the species observed here were diatoms and they can adapt to all light conditions (Richardson et al., 1983). 
Most of these species listed here have also been reported earlier by others reside in low light conditions such as Asterionella sp. (Zastrow, 2001), Chaetoceros spp. (Finkel et al., 2006), Coscinodiscus spp. (Key et al., 2010), Cyclotella sp. (Fisher et al., 1996), Ditylum sp. (Staehr et al., 2002), Fragilaria sp. (Karst-Riddoch et al., 2009), Prorocentrum sp. (Rodriguez et al., 2006), Skeletonema spp. (Anning et al., 2000), Synechococcus spp. (Barlow and Alberte, 1987), and Thalassiosira sp. (Dubinsky and Stambler, 2009).

Apart from the metabolic rate (growth, photosynthesis, respiration) light utilization by phytoplankton is also influenced by their size and shape (Raven, 1984; Kirk, 1994; Finkel, 2001). Morphometric and allometric parameters of phytoplankton are important indicators of the phytoplankton ecology and are related to the nutrient uptake, light utilization for photosynthesis (Vadrucci et al., 2013). Phytoplankton such as Thalassiosira spp., and Skeletonema spp., are filamentous types. The filamentous shape has better light antennae and therefore can photosynthesize with high capacity at low ambient light (Reynolds, 1997). Phytoplankton genera have been categorized according to their shapes (Sun and Liu, 2003) and the phytoplankton shapes observed here in low light were mostly cylindrical, rectangular box, a prism on parallelogram base and spherical, suggesting these shapes could be of advantage in efficient light harvesting.

The maximum solar light available was within the spectral range of 537 to $648 \mathrm{~nm}$ and the range varied for water types, and was 537 to $581 \mathrm{~nm}$ in the coastal waters, while it shifted to longer wavelengths 561 to 648 in the estuarine waters. The chromatic requirements can also be justified from the light absorbing properties by pigments in phytoplankton. The ubiquitous pigment present in all the phytoplankton is the chlorophyll a with major absorption occurring around $440 \mathrm{~nm}$. The absorptions of other pigments chlorophyll $\mathrm{b}$ (Chlb), chlorophyll c (Chlc), fucoxanthin (Fuco), $\beta$-carotene ( $\beta$ caro), and peridinin (Peri), have absorption peaks in the blue-green regions. Thus, it is evident that for photosynthesis blue-green light is essential. The phytoplankton surviving at low lights have a high efficient mechanism of light harvesting and utilizing every photon available (Stambler and Dubinsky, 2007; Dubinsky and Stambler, 2009; Halsey and Jones, 2015). The spectral light availability could change in future due to anthropogenic activities and climate change affecting the river run-off that will affect the optically active parameters such as the concentrations of CDOM, particle load (algal and non-algal), which could alter the underwater light field and spectral light in water. Hence, there is a need to understand the chromatic acclimation of these phytoplankton species observed in the low light.

Most of the primary production evaluated through models and measurements were limited to a lower limit of $1 \%$ light levels (Dubinsky, 2010) however it is noticed there were considerable amount of umbrophillic phytoplanktons below this $1 \%$ light levels and hence neglecting the contribution of these phytoplankton could underestimate the primary production and carbon related budgeting.

Monsoon plays an important role in the variations of turbidity and nutrient levels in these waters.

\section{Conclusion}

The study focused on the phytoplankton species of the estuaries and coastal waters of Goa in low light regions, which has been attempted for the first time for these waters. The results of the studies, even with this limited data, provided sufficient evidence of 
the various phytoplankton species, pigment variations, spectral light and the environmental conditions in the low light regions.

Though this study has been limited and preliminary in only reporting the phytoplankton communities and bio-optical conditions at low light levels, this could lay a foundation for the further studies related to phytoplankton acclimation in these waters. There are lots to understand of phytoplankton in the extreme light levels (Dubinsky, 2009). The light levels and nutrients in these estuaries and coastal waters could be affected by anthropogenic influence, monsoon and climatic changes and hence a continuous monitoring of the umbrophillic species of phytoplankton with regards to changes in these parameters will need to be studied to understand the phytoplankton acclimations in low light levels. There is also a gap in the present study without the information on the nutrients and this could have supplemented to understand the role of nutrients in the photoacclimation and light utilization efficiencies of these phytoplankton listed in the low light (Dubinsky and Schofield, 2010). Hence there is a scope to study the nutrient availability and the phytoplankton growth and related topics such as the limiting nutrient levels for the survival of various species of phytoplankton in low light depending on their size and characteristics, role of micro and macro nutrients, since the watershed of the estuaries of Goa include iron ore and manganese mines, the role micronutrients such as iron $(\mathrm{Fe})$ need to be studied.

Acknowledgements. The authors are grateful to the Director, CSIR-National Institute of Oceanography, Goa, India for the kind support. Authors are also indebted to the colleagues for the field measurements, discussions, and assistance in preparing the manuscript. This work was funded by ESSO-Indian National Centre for Ocean Observing System (INCOIS) under SATCORE program, Space Application Centre (ISRO) under MOP3 and NRSC (National Remote sensing centre) under NISCES programme.

\section{REFERENCES}

[1] Anning, T., MacIntyre, H. L., Pratt, S. M., Sammes, P. J., Gibb, S., Geider, R. J. (2000): Photoacclimation in the marine diatom Skeletonema costatum. - Limnol Oceanogr 45: 1807-1817.

[2] Barlow, G., Alberte, R. S. (1987): Photosynthetic characteristics of phycoerythrin containing marine Synechococcus spp. 11. Time course responses of photosynthesis to photoinhibition. - Marine Ecology-Progress Series 39: 191-196.

[3] Boyd, P. W., Strzepek, R., Fu, F., Hutchins, D. A. (2010): Environmental control of open-ocean phytoplankton groups: now and in the future. - Limnol Oceanogr 55: 13531376.

[4] Choudhury, N. K., Behera, R. (2001): Photoinhibition of photosynthesis: Role of carotenoids in photoprotection of chloroplast constituents. - Photosynthetica 39: 481-488.

[5] Cullen, J. J., Macintyre, J. G. (1998): Behavior, Physiology and the Niche of DepthRegulating Phytoplankton. - In: Anderson, D. M., Cembella, A. D., Hallegraeff, G. M. (eds.) Physiological Ecology of Harmful Algal Blooms. Springer-Verlag, Heidelberg.

[6] Desa, E., Suresh, T., Matondkar, S. G. P., Goes, J., Mascarenhas, A. A. M. Q., Parab, S. G., Shaikh, N., Fernandes, C. E. G. (2005): Detection of Trichodesmium bloom patches along the eastern Arabian Sea by IRS-P4/OCM ocean color sensor and by in-situ measurements. - Indian Journal of Marine Sciences 34: 374-386.

[7] Devassy, V. P., Goes, J. I. (1988): Phytoplankton community structure and succession in a tropical estuarine complex (Central West Coast of India). - Estuarine, Coastal and Shelf Science 27: 671-685. 
[8] Dias, A. B., Suresh, T., Sahay, A., Chauhan, P. (2017): Contrasting characteristics of colored dissolved organic matter of the coastal and estuarine waters of Goa during summer. - Indian Journal of Geo-Marine Science 46: 860-870.

[9] Dring, M. J. (1981): Chromatic adaptation of photosynthesis in benthic marine-algae-an examination of its ecological significance using a theoretical model. - Limnol Oceanogr 26: 271-284.

[10] Dubinsky, Z., Schofield, O. (2010): From the light to the darkness: Thriving at the light extremes in the oceans. - Hydrobiologia 639: 153-171.

[11] Dubinsky, Z., Stamble, N. (2009): Photoacclimation processes in phytoplankton: mechanisms, consequences, and applications. - Aquatic Microbial Ecology 56: 163-176.

[12] Fan, L., Vonshak, A., Gabbay, R., Hirshberg, J., Cohen, Z., Boussiba, S. (1995): The biosynthetic pathway of astaxanthin in a green algae Haematococcu spluvialis as indicated by inhibition with diphenylamine. - Plant Cell Physiol 36: 1519-1524.

[13] Finkel, Z. V. (2001): Light absorption and size scaling of light-limited metabolism in marine diatoms. - Limnol Oceanogr 46: 86-94.

[14] Finkel, Z. V. (2006): Irradiance and the elemental stoichiometry of marine phytoplankton. - Limnol Oceanogr 51: 2690-2701.

[15] Fisher, T., Minnaard, J., Dubinsky, Z. (1996): Photoacclimation in the marine algae Nannochloropsis sp. (Eustigmatophyte): a kinetic study. - Journal of Plankton Research 18: 1797-1818.

[16] Geider, R. J., Platt, T., Raven, J. A. (1986): Size dependence of growth and photosynthesis in diatoms: a synthesis. - Marine Ecology-Progress Series 30: 93-104.

[17] Gomes, H. D. R., Goes, J. I., Matondkar, S. G. P., Parab, S. G., Al-Azri, A. R. N., Thoppil, P. G. (2008): Blooms of Noctiluca miliaris in the Arabian Sea - an in situ and satellite study. Deep Sea Research Part I. - Oceanographic Research Papers 55: 751-765.

[18] Gorai, T., Katayama, T., Obata, M., Murata, A., Taguchi, S. (2014): Low blue light enhances growth rate, light absorption, and photosynthetic characteristics of four marine phytoplankton species. - Journal of Experimental Marine Biology and Ecology 459: 8795.

[19] Halsey, K. H., Jones, B. M. (2015): Phytoplankton strategies for photosynthetic energy allocation. - Annual Review of Marine Science 7: 265-297.

[20] Karst-Riddoch, T. L., Malmquist, H. J., Smol, J. P. (2009): Relationships between freshwater sedimentary diatoms and environmental variables in Subarctic Icelandic lakes. - Fundamental and Applied Limnology 175: 1-28.

[21] Key, T., McCarthy, A., Campbell, D. A., Six, C., Roy, S., Finkel, Z. V. (2010): Cell size trade-offs govern light exploitation strategies in marine phytoplankton. - Environ Microbio1 2: 95-104.

[22] Kirk, J. T. O. (1994): Light and Photosynthesis in Aquatic Ecosystems. - Cambridge University Press, Cambridge, UK.

[23] Krinsky, N. I. (1989): Antioxidant functions of carotenoids. - Free Radical Biology and Medicine 7: 617-635.

[24] Matondkar, P. S. G., Gomes, H. D., Parab, S. G., Pednekar, S., Goes, J. I. (2007): Phytoplankton Diversity, Biomass and Production. - In: Shetye, S. R., Kumar, D., Shankar, D. (eds.) The Mandovi and Zuari Estuaries. National Institute of Oceanography, Dona Paula, India.

[25] Moore, M. C., Suggett, D. J., Hickman, A. E., Kim, Y. N., Tweddle, J. F., Sharples, J., Geider, R. J., Holligan, P. M. (2006): Phytoplankton photoacclimation and photoadaptation in response to environmental gradients in a shelf sea. - Limnol Oceanogr 51: 936-949. doi: 10.4319/1o.2006.51.2.0936.

[26] Mueller, J. L. (2003): In-water Radiometric Profile Measurements and Data Analysis Protocols. - In: Mueller, J. L., G. S. Fargion, C. R. McClain (eds.) Ocean Optics Protocols for Satellite Ocean Color Sensor Validation, Revision 4, Volume III, pp. 7-20. NASA Goddard Space Flight Center, Greenbelt, Maryland. 
[27] Mueller, J. L., Fargion, G. S., McClain, C. R., Pegau, S., Zanefeld, J. R. V., Mitchell, B. G., Kahru, M., Wieland, J., Stramska, M. (2003): Ocean Optics Protocols for Satellite Ocean Color Sensor Validation. Volume IV: Inherent Optical Properties: Instruments, Characterizations, Field Measurements and Data Analysis Protocols. - NASA Goddard Space Flight Center, Greenbelt, Maryland.

[28] Naqvi, S. W. A., George, M. D., Narvekar, P. V., Jayakumar, D. A., Shailaja, M. S., Sardessai, S., Sarma, V. V. S., Shenoy, D. M., Naik, H., Maheswaran, P. A., KrishnaKumari, L., Rajesh, G., Sudhir, A. K., Binu, M. S. (1998): Severe fish mortality associated with red tide observed in the sea off Cochin. - Current Science 75: 543-544.

[29] Naqvi, S. W. A., Jayakumar, D. A., Narvekar, P. V., Naik, H., Sarma, V. V. S. S., D'souza, W., Joseph, S., George, M. D. (2000): Increased marine production of $\mathrm{N}_{2} \mathrm{O}$ due to intensifying anoxia on the Indian continental shelf. - Nature 408: 346-349.

[30] Naqvi, S. W. A., Naik, H., Jayakumar, D. A., Shailaja, M. S., Narvekar, P. V. (2006): Seasonal Oxygen Deficiency over the Western Continental Shelf of India. - In: Neretin, L. N. (ed.) Handbook of Past and Present Water Column Anoxia. Springer, Dordrecht.

[31] Overmann, J., Garcia-Pichel, F. (2005): The Phototrophic Way of Life. - In: Dworkin, M. (ed.) The Prokaryotes: An Evolving Electronic Resource for the Microbiological Community. Springer, New York.

[32] Parab, S. G., Matondkar, S. G. P., Gomes, H. D. R., Goes, J. I. (2006): Monsoon-driven changes in phytoplankton populations in the eastern Arabian Sea as revealed by microscopy and HPLC pigment analysis. - Continental Shelf Research 26: 2538-2558.

[33] Patil, S., Anil, A. C. (2011): Variations in phytoplankton community in a monsooninfluenced tropical estuary. - Environ Monit Assess 182: 291-300.

[34] Pednekar, S. M., Prabhu Matondkar, S. G., VijayaKerkar. (2012): Spatiotemporal distribution of harmful algal flora in the tropical estuarine complex of Goa, India. - The Scientific World Journal 2012: 1-11.

[35] Pednekar, S. M., Kerkar, V., Matondkar, S. G. P. (2014): Spatiotemporal distribution in phytoplankton community with distinct salinity regimes along the Mandovi estuary, Goa. India. - Turk J Bot 3: 800-818.

[36] Pinchasov-Grinblat, Y., Hoffman, R., Dubinsky, Z. (2011): The effect of photoacclimation on photosynthetic energy storage efficiency, determined by photoacoustics. - Open Journal of Marine Science 1: 43-49.

[37] Raven, J. A. (1984): A cost-benefit analysis of photon absorption by photosynthetic unicells. - New Phytologist 98: 593-625.

[38] Raven, J. A., Cockell, C. S. (2006): Influence on photosynthesis of starlight, moonlight, planet light, and light pollution (reflections on photosynthetically active radiation in the universe). - Astrobiology 6: 668-675.

[39] Raven, J. A., Kübler, J. E., Beardall, J. (2000): Put out the light, and then put out the light. - J. Mar. Biol. Assoc. 80: 1-25.

[40] Reynolds, C. S. (1997): Vegetation Processes in the Pelagic. A Model for Ecosystem Theory. - ECI, Oldendorf.

[41] Richardson, K., Beardall, J., Raven, J. A. (1983): Adaptation of unicellular algae to irradiance: an analysis of strategies. - New Phytol 93: 157-191.

[42] Rodriguez, F., Chauton, M., Johnsen, G., Andresen, K., Olsen, L. M., Zapata, M. (2006): Photoacclimation in phytoplankton: implications for biomass estimates, pigment functionality and chemotaxonomy. - Marine Biology 148: 963-972.

[43] Ryther, J. H., Menzel, D. W. (1959): Light adaptation by marine phytoplankton. - Limnol Oceanogr 4: 492-497.

[44] Santhanam, R. N., Ramanathan, Venkataramanujan, K., Jegatheesun, G. (1987): Phytoplankton of the Indian seas. - Daya Publication House, Delhi. http://www.nal.usda.gov.

[45] Schagerl, M., Muller, B. (2006): Acclimation of chlorophyll a and carotenoid levels to different irradiances in four freshwater cyanobacteria. - J Plant Physiol 163: 709-716. 
[46] Shetye, S. R., Shankar, D., Neetu, S., Suprit, K., Michael, G. S., Chandramohan, P. (2007): The Environment That Conditions the Mandovi and Zuari Estuaries. - In: Shetye, S. R., Kumar, D., Shankar, D., (eds.) The Mandovi and Zuari Estuaries. National Institute of Oceanography, Dona Paula, India.

[47] Staehr, P. A., Henriksen, P., Markager, S. (2002): Photoacclimation of four marine phytoplankton species to irradiance and nutrient availability. - Aquatic Microbial Ecology 238: 47-59.

[48] Stambler, N., Dubinsky, Z. (2007): Marine Phototrophs in the Twilight Zone. - In: Seckbach, J. (ed.) Algae and Cyanobacteria in Extreme Environments. Series: Cellular Origin, Life in Extreme Habitats and Astrobiology. Springer, Dordrecht.

[49] Sun, J., Liu, D. (2003): Geometric models for calculating cell bio volume and surface area for phytoplankton. - J Plankton Res 25: 1331-1346.

[50] Suresh, T., Desa, E., Desai, R. G. P., Jayraman, A., Mehra, P. (1996): Photosynthetically available radiation in the central and eastern Arabian sea. - Current Science 71: 883-887.

[51] Thadathil, P., Gosh, A. K. (1992): Surface layer temperature inversion in the Arabian Sea during winter. - Journal of Oceanography 48: 293-304.

[52] Tomas, C. R. (1997): Identifying Marine Phytoplankton. - Academic Press, San Diego, CA.

[53] Vadrucci, M. R., Mazziott, C., Fiocca, A. (2013): Cell biovolume and surface area in phytoplankton of Mediterranean transitional water ecosystems: methodological aspects. Transitional Waters Bulletin 7: 100-123.

[54] Verlencar, X. N. (1987): Distribution of nutrient in the coastal and estuarine waters of Goa. - Mahasagar Bulletin of the National Institute of Oceanography 20: 205-215.

[55] Vijith, V., Sundar, D., Shetye, S. R. (2009): Time-dependence of salinity in monsoonal estuaries. - Estuarine, Coastal and Shelf Science 85: 601-608.

[56] Wang, M. C., Bohmann, D., Jasper, H. (2003): JNK signaling confers tolerance to oxidative stress and extends lifespan in drosophila. - Developmental Cell 5: 811-816.

[57] Zastrow, J. C. (2001): Photoacclimation of the Diatom Asterionellaformosa in a Simulated Vertically Mixed Water Column. - The University of Wisconsin, Milwauke. 